\title{
EVALUAREA CALITĂȚII BIOMASEI DE Lolium perenne L. CA FURAJ ȘI SUBSTRAT PENTRU OBȚINEREA BIOMETANULUI
}

\author{
Ţîţei Victor ${ }^{1}$, Blaj Adrian Vasile ${ }^{2}$, Andreoiu Andreea Cristina ${ }^{2}$, Marușca Teodor $^{2}$ \\ ${ }^{1}$ Grădina Botanică Națională (Institut) „,Alexandru Ciubotaru”, Chişinău, Republica Moldova \\ ${ }^{2}$ Institutul de Cercetare-Dezvoltare pentru Pajiști, Brașov, România \\ *e-mail: vtitei@mail.ru
}

\begin{abstract}
We studied the biochemical composition, nutritive value of the green mass and prepared hay from Romanian cultivars of perennial ryegrass, Lolium perenne L. „Mara” and „Măgura” grown in monoculture on the experimental plot of the National Botanical Garden (Institute) "Alexandru Ciubotaru”, Chisinau, R. Moldova. Results revealed that dry matter of harvested green mass contained 98-116 g/kg CP, 299-326 g/kg CF, $71-77 \mathrm{~g} / \mathrm{kg}$ ash, 329-353 g/kg ADF, 546-593 g/kg NDF, 38-40 g/kg ADL, 291-313 g/kg Cel, 217-240 g/kg $\mathrm{HC}$, with nutritive and energy value 60.9-65.3 \% DMD, 60.1-64.8 \% ODM, RFV=96-108, 12.12-12.45 MJ/kg $\mathrm{DE}, 9.95-10.23 \mathrm{MJ} / \mathrm{kg} \mathrm{ME}$ and 5.97-6.25 MJ/kg NEl. The biochemical composition, nutritive and energy value of prepared hay: $94-110 \mathrm{~g} / \mathrm{kg} \mathrm{CP}, 351-385 \mathrm{~g} / \mathrm{kg} \mathrm{CF}, 79-82 \mathrm{~g} / \mathrm{kg}$ ash, 390-423 g/kg ADF, 631-689 g/kg NDF, 46-50 g/kg ADL, 344-373g/kg Cel, 241-266 g/kg HC, RFV=76-86, 11.13-11.61 MJ/kg DE, 9.14- 9.53 $\mathrm{MJ} / \mathrm{kg} \mathrm{ME}$ and 5.17-5.55 MJ/kg NEl. The biochemical methane potential of green mass substrates reached $338-344 \mathrm{~L} / \mathrm{kg}$ organic matter. The studied cultivars of Lolium perennec could be used in the Republic of Moldova for the restoration of degraded permanent grasslands, as a component of the mix of grasses and legumes for the creation of temporary grasslands, the harvested biomass can be used as feed for farm animals or as substrate in biogas generator for renewable energy production.
\end{abstract}

Key words: biochemical composition, biochemical methane potential, green mass, hay, Lolium perenne, cv. „Mara”, cv. „Măgura”, nutritive value

\section{Introducere}

Ierburile perene constituie o grupă de specii importante pentru vegetaţia pajiştilor, sunt dominante în majoritatea tipurilor de pajişti permanente din ţara noastră, cât şi în compoziţia floristică a pajiştilor temporare, asigură hrană și adăpost pentru păsări și animale, materie primă pentru diferite industrii, contribuie la menținerea fertilității și protecției resurselor de sol.

Genul Lolium L. face parte din subtribul Loliinae, tribul Poeae, subfamilia Pooideae, familia Poaceae Barnhart (sin. Gramineae Juss.), cuprinde 11 de specii cu distribuție mondială. În flora spontană a Basarabiei se întâlnesc 2 specii: Lolium multiflorum Lam. și Lolium perenne L.

Raigrasul peren, Lolium perenne L., cunoscut și ca zizanie perenă, raigras englez, iarba de gazon este o specie perenă originară din Europă, Asia și Africa Nord, se întâlnește și în flora spontană locală în locuri umede, pajiștile de câmpie și dealuri, marginea drumului, pe soluri profunde și bogate, cu tufă rară, deseori deasă, cu tulpini subţiri, erecte, decumbente sau rareori prostrate, uneori înrădăcinate la nodurile cele mai joase, de obicei cu 2-4 noduri și înălţimea de 40-100 cm, de culoare verde, lăstarii tineri la baza sunt de culoare roșie violacee. Frunzele sunt plane, cu multe nervuri, lungi de 14-30 cm și late de 1-6 mm, treptat ascuţite la vârf, glabre și strălucitoare pe faţa inferioară, glabre pe faţa, superioară, cu margini glabre până la scaberuloase, de culoare verde intens, frunzele tinere sunt pliate; auriculele ating $3 \mathrm{~mm}$; ligula 2-2,5 mm. Spicul lung de până la $20 \mathrm{~cm}$ lungime, cu 8-15 spiculeţe multiflore ce au o singură glumă de 6$8 \mathrm{~mm}$, în afară de spiculeţul terminal care are două glume. Spiculeţele sunt așezate cu partea îngustă pe rahis, într-o adâncitură a acestuia. Paleea inferioară nearistată, nemembranoasă, ovat lanceolată, cu crenă puternică, lung ciliată, arestată la vârf, cu 3-5 nervuri evidente mai ales la bază, paleea superioară mai mică cu marginile acoperite de cea inferioară. Înflorește în mai-iunie, polenizarea este alogamă anemofilă. Sămânţa cariopsă de culoare galbenă-maronii, concrescută cu solzi integumentari, lungă de 4.5-6.3 mm și lată de 0.8-1.5 mm. Masa a 1000 seminţe $0.85-1.46$ g. Potenţialul de producţie de sămânţă $650-800 \mathrm{~kg} / \mathrm{h}$. Raigrasul peren formează un sistem radicular fascicular, nu dezvoltă stoloni sau rizomi, nodul de înfrăţire 
se formează în sol la adâncimea de 1-2 cm, se atestă formarea de rădăcini aeriene pe nodul de tulpină la nivelul sau aproape de nivelul solului la plantele tinere, dar se pot dezvolta și din nodur mai înalte la plante mai mari. Rădăcinile nodale sunt variabile și pot fi albe, groase, lucioase, drepte, neramificate și acoperite cu perișori fini, devenind pe parcurs fibroase. Sistemul radicular se extinde în sol la adâncime de 80 $\mathrm{cm}$. Raigrasul peren este sensibil la fluctuaţiile de umiditate din sol, în condiţii de secetă se atestă o diminuare a producţiei de biomasă aeriană, iar în condiţii de secetă severă pedologică și arșiță plantele pier și se formează golurilor. Are o gamă largă de adaptabilitate la tipul și textura solului, crește cel mai bine pe soluri fertile argiloase, bine drenate, tolerează atât solurile acide, cât și cele alcaline (pH 5.2 - 8.0). A fost introdus în cultură în Anglia, la începutul secolului al XVIII-lea, după ce s-a răspândit în cultură largă în Eurasia, Australia, America în secolul XIX-XX. Această specie este studiată în numeroase centre de cercetare, fiind create și implementate soiuri folosite în cultură pură sau în amestecuri cu alte ierburi și leguminoase pentru recultivarea pajiștilor permanente și fondarea pajiștilor semănate pentru furaj și substrat, înierbarea terenurilor erodate și accidentate, arenelor sportive, zonelor de agrement și relaxare. Raigrasul peren rezistă foarte bine la păşunat şi călcare, productivitatea de 35-45 t/ha masă proaspătă, 9-13 t/ha substanţă uscată cu valoare furajeră foarte bună $[6,7,9,10]$.

În Catalogul soiurilor de plante a Republicii Moldova nu sunt înregistrate soiuri de raigras peren. Scopul cercetării a constat în evaluarea calităţii masei proaspete și a fânului a unor soiuri românești de raigras peren Lolium perenne L. cultivate în condițiile Republicii Moldova.

\section{Materiale şi metode}

În calitate de obiect de studiu a servit plantele de raigras peren Lolium perenne L. soiurile „Mara” și „Măgura" create la Institutul de Cercetare-Dezvoltare pentru Pajiști, Brașov, România, cultivate în terenul experimental al Grădinii Botanice Naţionale (Institut) „Alexandru Ciubotaru” din Chişinău. Mostrele de masă proaspătă pentru cercetări au fost prelevate din parcele din anul 2 de vegetație în perioada de înspicare, mărunţite şi supuse deshidratării în etuvă cu ventilaţie forţată la temperatura de $60^{\circ} \mathrm{C}$, la finele fixării materialul biologic a fost măcinat fin la moara de laborator cu bile. Mostrele de fân au fost prelevate din masa cosită și uscată în brazdă direct în câmp. Evaluarea conținutului de proteina brută (CP), cenuşa brută (CA), fibră brută (CF), conţinutul de fibre prin tratare cu detergent neutru (NDF), conţinutul de fibre prin tratare cu detergent acid (ADF), conţinutul de lignină sulfurică (ADL), lignină sulfurică (ADL), substanţă uscată digestibilă (DDM), materie organică digestibilă (ODM) aplicând metoda spectrofotometriei infraroșu apropiat cu utilizarea echipamentului tehnic PERTEN DA 7200 din cadrul Institutul de Cercetare-Dezvoltare pentru Pajiști Brașov, Romania cu metode standardizate. Conținutul de celuloză (Cel), hemiceluloză (HC), valoarea relativă a furajului (RFV), energia digestibilă (DE), energie metabolizantă (ME), energie netă lactaţie (NEl) s-a estimat conform ecuațiilor acceptate. Conținutul de carbon în materia organică s-a calculat conform ecuației reportate de Badger și col. [3]. Potențialul de producție a biogazului și randamentul specific de metan au fost evaluate pe baza conținutului de proteină brută și a compușilor chimici a pereților celulari lignină sulfurică și hemiceluloză a masei proaspete recoltate conform ecuațiilor reportate de Dandikas și col. [5].

\section{Rezultate şi discuţii}

Am putea menționa că în anul 2 de vegetație regenerarea plantelor de raigras peren a soiurilor cercetate s-a observat la finele lunii martie, o creștere și dezvoltare mai intensă s-a stabilit în a doua jumătate a lunii aprilie. La momentul recoltării, mijlocul lunii mai, soiurilor cercetate aveau înălțimea de $68-72 \mathrm{~cm}$, conținutul de substanțe uscate în masa proaspătă recoltată de 30-31\%. Plantele soiului „Mara” dezvoltă tulpini mai lungi, dar cu un grad mai diminuat de înfrunzire. Rezultatele privitor la compoziţia biochimică și valoarea nutritivă a substanțelor uscate din masa recoltată a soiurilor cercetate de raigras peren sunt prezentate în tabelul 1. S-a stabilit că furajul natural din soiul „Măgura” se evidențiază printr-un conținut mai diminuat de fibră brută, hidrați de carbon structurali și mai ridicat de proteină brută, fapt ce s-a răsfrânt pozitiv asupra valorii nutritive și asigurării cu energie metabolizantă și energie netă lactației a furajului.

Fânul este un nutreţ valoros pentru animalele de fermă, sprijină funcţiile motorii ale burdufului, adică activitatea musculară a sistemului digestiv şi rumegatul, activitate indispensabila pentru o valorificare corespunzătoare a hranei și asigurarea bunăstării animalelor. 
S-a stabilit că în procesul de preparare a fânul de raigras peren, Tabelul 1, crește conținutul de fibră brută, celuloză, hemiceluloză, lignină sulfurică, cenușă și se diminuează conținutul de proteină comparativ cu masa proaspătă, fapt ce s-a răsfrânt asupra diminuării valorii nutritive.

În literatura de specialitate, sunt prezentate date privitor la calitatea furajului de Lolium perenne. Astfel, Duke [6] reportează că masa proaspătă conţine 26.6\% S.U., 3.0\% proteină, 1.3\% grăsimi, $6.7 \%$ fibră brută, $13.2 \%$ substanțe extractive neazotate, $2.4 \%$ cenușă, iar fânul $88 \%$ S.U., $9.2 \%$ proteină, $3.1 \%$ grăsimi, $24.2 \%$ fibră brută, $43.4 \%$ substanțe extractive neazotate, $8.1 \%$ cenușă.

Tabelul 1. Compoziţia biochimică şi valoarea nutritivă a masei proaspete și a fânului de Lolium perenne

\begin{tabular}{|l|c|c|c|c|}
\hline \multirow{2}{*}{\multicolumn{1}{|c|}{ Componenți }} & \multicolumn{2}{c|}{ Masă proaspătă } & \multicolumn{2}{c|}{ Fân } \\
\cline { 2 - 5 } & s. Mara & s. Măgura & s. Mara & s. Măgura \\
\hline Proteină brută (CP), g/kg & 98 & 116 & 94 & 110 \\
Fibră brută (CF), g/kg & 326 & 299 & 385 & 351 \\
Fibră în acid detergent (ADF), g/kg & 353 & 329 & 423 & 390 \\
Fibră în detergent neutru (NDF), g/kg & 593 & 546 & 689 & 631 \\
Lignină sulfurică (ADL), g/kg & 40 & 38 & 50 & 46 \\
Celuloză (Cel), g/kg & 313 & 291 & 373 & 344 \\
Hemiceluloză (HC), g/kg & 240 & 217 & 266 & 241 \\
Cenuşă brută (CA), g/kg & 71 & 77 & 79 & 82 \\
Substanţă uscată digestibilă (DDM),\% & 60.9 & 65.3 & 47.7 & 55.6 \\
Materie organică digestibilă (ODM),\% & 60.1 & 64.8 & 44.9 & 52.6 \\
Energie digestibilă (DE), MJ/kg & 12.12 & 12.45 & 11.13 & 11.61 \\
Energie metabolizantă (ME), MJ/kg & 9.95 & 10.23 & 9.14 & 9.53 \\
Energie netă lactație (NEl), MJ/kg & 5.97 & 6.25 & 5.17 & 5.55 \\
Valoarea nutritivă relativă (RFV) & 96 & 108 & 76 & 86 \\
\hline
\end{tabular}

Aitchison și col. [1] menționează că fânului de raigras peren conține 911 g/kg materie organică, 619 $\mathrm{g} / \mathrm{kg} \mathrm{NDF}, 332 \mathrm{~g} / \mathrm{kg}$ ADF. Conform datelor prezentate de Nicolae [8] plantele de raigras peren conțin 164-275 g/kg S.U., 7.3-14.2\% proteină, 1.8-2.5 \% grăsimi, 23.9-32.9\% fibră brută, 8.5-10.2\% cenușă, 47.4-50.0\% substanțe extractive neazotate, iar fânul respectiv 6.9-11.5\% proteină, 1.2-1.4 \% grăsimi, 28.7-34.7\% fibră brută, 8.7-9.1\% cenușă, 47.4-49.7\% substanțe extractive neazotate, $0.64-0.81$ UNL/kg și 0.55-0.74 UFV/kg. Silva Déley și col. [9] raportează că fânul conţine 163.4-183.3 g/kg CP, 274.7-320.9 g/kg CF, 71.2-115.3 g/kg CA, 612-637 g/kg NDF, 508-521 g/kg ADF, 41-43 g/kg ADL, 65.99-71.13\% DDM, 66.73-73.70\% ODM.

Tabelul 2.Potenţialului de obținere a biometanului din masa proaspătă de Lolium perenne

\begin{tabular}{|l|c|c|}
\hline \multicolumn{1}{|c|}{ Indici } & \multicolumn{2}{c|}{ Soiuri } \\
\cline { 2 - 3 } & Mara & Măgura \\
\hline Carbon, g/kg & 516.11 & 512.78 \\
Azot, g/kg & 15.68 & 18.56 \\
Raportul carbon : azot (C/N) & 33 & 28 \\
Proteină brută (CP), g/kg & 98 & 116 \\
Lignină sulfurică (ADL), g/kg & 40 & 38 \\
Hemiceluloză (HC), g/kg & 240 & 217 \\
Potențial biometan, $1 / \mathrm{kg} \mathrm{MO}$ & 630 & 642 \\
Potențial biometan, $1 / \mathrm{kg}$ MO & 338 & 344 \\
\hline
\end{tabular}

Este cunoscut faptul că în procesul de digestie anaerobă a biomasei se obține biogazul, bogat în metan ca combustibil pentru producerea energiei renovabile și digestatul ca sursă de nutrienți pentru fertilizarea plantelor în sistemul de agricultură organică. Rezultatele privitor la calitatea masei proaspete de $L o$ lium perenne ca substrat pentru digestie anaerobă și potenţialului de obținere biometanului sunt prezentate în Tabelul 3. Am putea menționa că substraturile investigate se evidențiază printr-un conținut ridicat de hemiceluloză, moderat de substanțe proteice și de lignină sulfurică, raport optimal carbon : azot, fapt ce 
asigură un potenţialul de obținere biometanului de 338-344 1/kg materie organică. Dai și col. [4] menționează că biomasa de Lolium perenne are un raport $\mathrm{C} / \mathrm{N}=17$ și potențial de biometan de $310 \mathrm{l} / \mathrm{kg}$. Amaleviciute-Volunge și col. [2] raportează că substratul de Lolium perenne conţine $102.8 \mathrm{~g} / \mathrm{kg} \mathrm{CP}, 66.7 \mathrm{~g} / \mathrm{kg}$ CA, $547.5 \mathrm{~g} / \mathrm{kg} \mathrm{NDF}, 328 \mathrm{~g} / \mathrm{kg}$ ADF, $39.7 \mathrm{~g} / \mathrm{kg}$ ADL, $289 \mathrm{~g} / \mathrm{kg}$ Cel, $219 \mathrm{~g} / \mathrm{kg} \mathrm{HC}, 57.9 \%$ DDM, 45.9\% C, $1.63 \% \mathrm{~N}, 304.31 / \mathrm{kg}$ biogas și $205.71 / \mathrm{kg}$ metan.

\section{Concluzii}

Soiurile cercetate de raigras peren Lolium perenne asigură un furaj de calitate și ar putea fi utilizate în Republica Moldova pentru refacerea pajiștilor permanente degradate, ca o componentă a amestecului de ierburi și leguminoase pentru crearea pajiștilor temporare, de asemenea pentru înierbarea între rânduri în vii și livezi, iar biomasa recoltată poate fi folosită ca hrană pentru animale de fermă în stare proaspătă sau sub formă de fân, dar și ca substrat pentru obținerea biometanului.

Cercetările au fost realizate în cadrul proiectului „,Mobilizarea resurselor genetice vegetale, ameliorarea soiurilor de plante şi valorificarea lor ca culturi furajere, melifere şi energetice în circuitul bioeconomic", cifrul 20.80009.5107.02.

\section{Bibliografie}

1. AITCHISON, E.M., GILL, M., D.F. OSBOURNT, D.F., 1986. The effect of supplementation with maize starch and level of intake of perennial ryegrass (Lolium perenne cv. Endura) hay on the removal of digesta from the rumen of sheep. British Journul of Nutrition, 56: 471-486.

2. AMALEVICIUTE-VOLUNGE, K., SLEPETIENE, A., BUTKUTE, B., 2020. Methane yield of perennial grasses as affected by the chemical composition of their biomass. Zemdirbyste-Agriculture, 107 (3): 243-248.

3. BADGER, C.M., BOGUE, M.J., STEWART, D.J., 1979. Biogas production from crops and organic wastes. New Zeland Journal of Science, 22:11.

4. DAI, X., LI, X., ZHANG, D., CHEN, Y., DAI, L., 2016. Simultaneous enhancement of methane production and methane content in biogas from waste activated sludge and perennial ryegrass anaerobic co-digestion: the effects of $\mathrm{pH}$ and $\mathrm{C} / \mathrm{N}$ ratio. Bioresource Technology, 216:323-330.

5. DANDIKAS, V., HEUWINKEL, H., LICHTI, F., DREWES, J.E., KOCH, K., 2015. Correlation between biogas yield and chemical composition of grassland plant species. Energy Fuels, 29 (11): 7221-7229.

6. DUKE, J.A., 1983. Handbook of Energy Crops. http://www.hort.purdue.edu/newcrop/duke_energy/Lolium_perenne.html

7. MARUŞCA, M., TOD, M., SILISTRU, D., DRAGOMIR, N., SCHITEA, M., 2011. Principalele soiuri de graminee şi leguminoase perene de pajişti. Braşov: Capolavoro. $52 \mathrm{p}$.

8. NICOLAE, M., 2016. Ghid de formulare a rațiilor și a nutrețurilor combinate. București, 101p.

9. SILVA, DÉLEY, LUCIA, M. et al., 2019. Forages quality of Cenchrus clandestinum and Lolium perenne forages in the form of hay at different regrowth ages. Cuban Journal of Agricultural Science, 53(3): 299-306.

10.ȚITTEI, V., ROŞCA, I., 2021. Bunele practici de utilizare a terenurilor degradate în cultivarea culturilor cu potenţial de biomasă energetică. Chişinău, 80 p. 